\title{
リソグラフィで転写した凹面レジストパターンを利用した マイクロレンズアレイの製作と評価*
}

\author{
小林野歩**笹木龍之介苞堀内敏 行 $^{\dagger}$ \\ Fabrication of Micro-Lens Arrays Utilizing Lithographically Replicated Concave Resist Patterns \\ and Evaluation of Lens Characteristics
}

Noa KOBAYASHI, Ryunosuke SASAKI and Toshiyuki HORIUCHI

\begin{abstract}
Lithography has been generally used for printing two-dimensional patterns on flat wafers. Recently, however, it is also applied to a three-dimensional patterning for fabricating various MEMS (Micro Electro Mechanical Systems) components. In this research, plastic micro-lens arrays are fabricated utilizing lithographically replicated quasi-spherical concave resist patterns. At first, resist (Tokyo Ohka Kogyo, PMER P-LA900 PM) patterns with densely arrayed hexagonal concaves were replicated by intentionally shifting the focal position of projection exposure. As an exposure system, a handmade 1/19 reduction projection system with a field size of $2-\mathrm{mm}$ square was used. The initial resist thickness was approximately 10 $\mu \mathrm{m}$. Next, liquid epoxy resin (Nissin resin, Crystal resin Neo) was injected on the concave resist-mold patterns and coagulated. To control the total thickness of hardened resin-lens arrays including the back-side flat part and secure the smoothness and transparency, the resin thickness was controlled by attaching an acrylic lid covering the surface of resist-mold patterns. Finally, focusing performances of the resin lens array were also demonstrated. Using a lens array with a pitch of $42.1 \mu \mathrm{m}$, a curvature radius of $28.3 \mu \mathrm{m}$, and a height of $4.9 \mu \mathrm{m}$, focused light spots with a diameter of approximately $3 \mu \mathrm{m}$ in diameter were obtained.
\end{abstract}

Key words: projection lithography, micro-lens array, plastic lens, concave resist pattern

\section{1. 緒言}

フォトリソグラフィ技術は半導体素子の小型化, 高集積化の コア技術であり, 長年平面微細加工を施す二次元加工技術とし て使われてきた 1)-5). しかし，近年 MEMS(Micro Electro Mechanical Systems) などの三次元加工にも応用されている 6)-9). 一方, 三次元加工用の微細加工技術として, 多層に露光を 繰り返して任意形状を得る光造形法がある. しかし，この造形 法は高さ方向に曲面を加工しようとすると, 加工物の側壁が滑 らかにならず, ステップ状の形状になってしまうという課題が ある 10)-12). そのためグレースケール・リソグラフィ 13)15)や, 熱リ フロー16)-18)などで曲面を形成する研究が行われている. しかし， グレースケールでは半透明部を形成するためにドットパターン を用いるためレチクルが高価になってしまい, 熱リフローでは 制御できるパラメータが温度と粘度の二つであるため形成の任 意性がそしいと考えられる.

先行研究において, 露光波長を適切に選んで光の吸収量を調 節し, 結像位置を意図的にずらすという三つのパラメータを制 御することにより, 側壁に段差が無く滑らかな曲面や傾斜形状 を高価なドットパターンレチクルを用いずに形成する方法が検 討され，レジストの側壁を制御してパターンを形成できること が示された 1920). そこで本研究では，この技術を応用し，レジス トにマイクロレンズアレイの型とする密接した凹状のパターン アレイを形成し，そこに透明樹脂を流し込むことによってマイ

*原稿受付 平成 28 年 12 月 20 日

揭載決定 平成 29 年 5 月 17 日

**学生会員 東京電機大学（東京都足立区千住旭町 5)

***東京電機大学

正 会 員 東京電機大学
クロレンズアレイを製作した ${ }^{21}$.レジストパターンを剥離して 取り出した樹脂製レンズアレイの基本的な光学特性の評価も行 った. マイクロレンズアレイは光通信, 撮像素子, ディスプレイ などに用いられており, 性能を向上させるためにより微細なレ ンズを効率的に生産できる技術が求められている. 開発した方 法はニーズに答え得る一つの有効な方法である.また, マイクロ レンズアレイのレプリカ製作の研究として,等方ウェットエッチ ング 22123)やマイクロ切削 24)-26)などがあるが, 等方ウェットエッ チングは深さ方向と水平方向のエッチング量を独立に制御でき ないので, レンズの形状の任意性に乏しい. マイクロ切削は要 素レンズ 1 個ずつの加工なのでレンズ数が多いと加工に時間が かかり加工工具で形状が決まるので, 形状が少しずつ変形した り，まず工具を精度よく作らなければならないという課題があ る. 本研究ではフォトリソグラフィを利用することで量産向き かつ, 縮小投影による微細化ができると考えている.

\section{2. 凹面レジストパターンの形成}

まず, フォトリソグラフィによりレンズアレイの型とする凹 面レジストパターンを形成した. レジストパターンの形成に用 いた投影露光装置の構成を図 1 に示す. 寸法は横 $300 \mathrm{~mm}$, 奥行 き $600 \mathrm{~mm}$, 高さ $970 \mathrm{~mm}$ である.

露光光源は特殊紫外線光源(住田光学ガラス, LS-140UV) で あり, 照射された光のうちバンドパスフィルタによって $405 \mathrm{~nm}$ のみを取り出して露光に用いた. そしてその露光光を, 対辺間 隔が $500 \mu \mathrm{m}$ の六角形の透過部と幅 200〜 400 $\mu \mathrm{m}$ の遮光部を六 角最密充填構造に配置したレチクルに照射した.レチクルパタ ーンを図 2 に示す. 


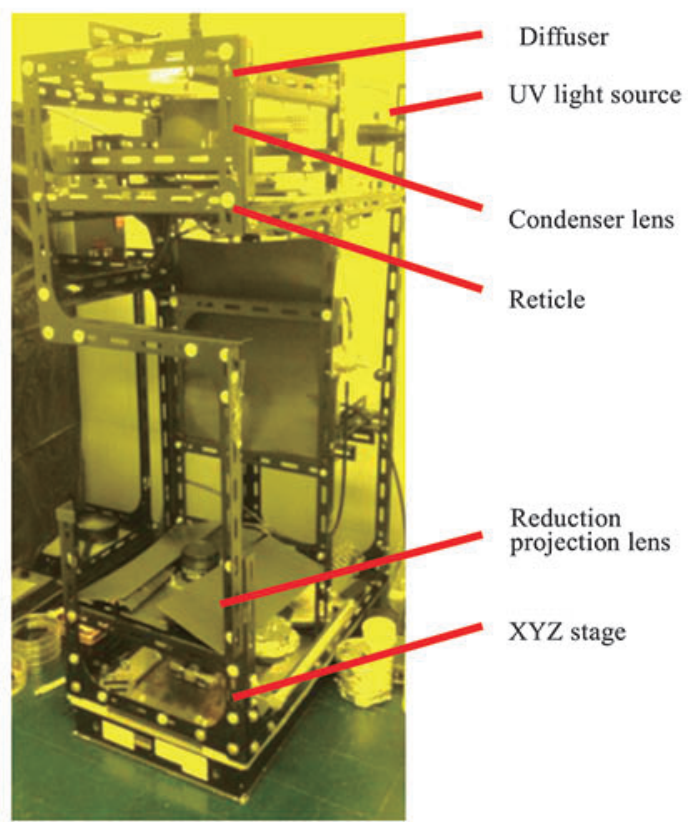

Fig.1 External view of the projection exposure system

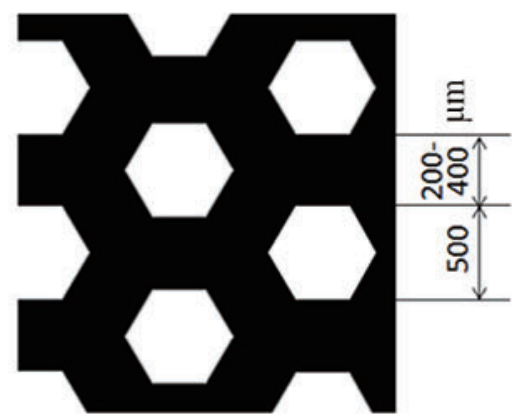

Fig.2 Hexagonal patterns on the reticle

レチクル照明光を用い, 直径 $4 \mathrm{~mm}$ のピンホールを設けた縮 小投影レンズを介してレチクルパターンを $1 / 19$ に縮小し, Si ウ エハ上に染布した膜厚 $10 \mu \mathrm{m}$ のポジ型レジスト(東京応化工業 PMER P-LA900PM) 上に投影した. このレジストは光に感光 すると内部の透過率が上昇する特性を持つ. そのため適切な波 長を選定することによりレジストの上部と底部の露光量にレン ズ製作に適した差を生じさせることができるため所望の曲面形 状が得られると考えて採用した. 縮小レンズとしてはカメラレ ンズ(キヤノン, NFD28/2.8) を用い, Fナンバは 4 とした. 現像 液としては PMER P-7G(東京応化工業) を用いた.

露光後現像時にレジスト側壁が最も垂直に近づく焦点位置を ベストフォーカス位置とするとき, 焦点位置をウエハがレンズ から遠ざかる方向(+方向)に意図的にずらしてパターン像をぼ やけさせて投影した. こうすることにより, レジストの断面が 矩形状ではなく曲面形状の側壁が形成できた. 図 2 のレチクル を使用して露光量 $384 \mathrm{~mJ} / \mathrm{cm}^{2}$ で焦点位置を変えたときの凹面 レジストパターンの断面形状を走查型電子䫓微鏡 (JEOL JSM-5510) で観察すると, 図 3 に示すように変化した. 図から 分かるように, 焦点位置 $+150 \mu \mathrm{m}$ で最もレンズ形状に適した凹 面形状を得ることができた.

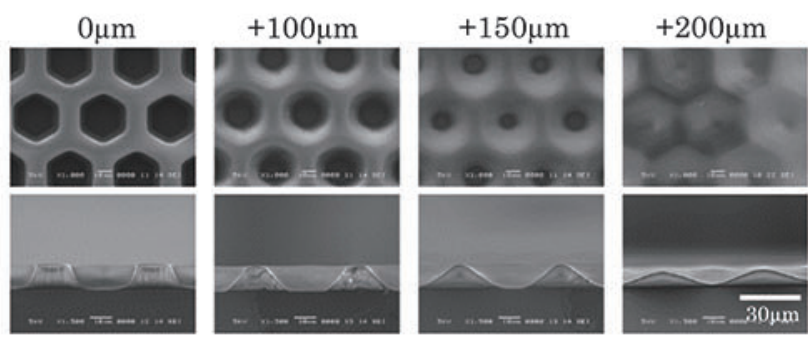

Fig.3 Concave resist surface used as the mold of lens array

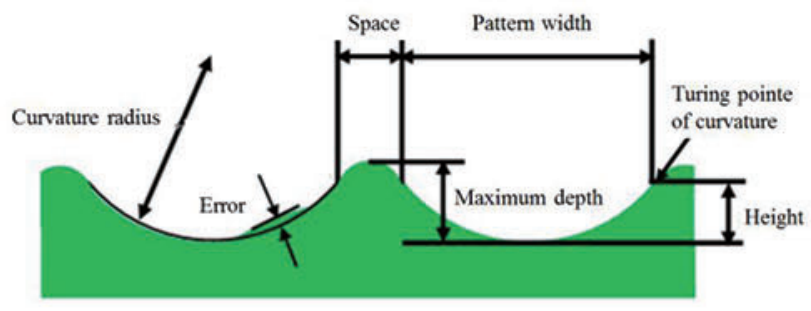

Fig.4 Measurement condition

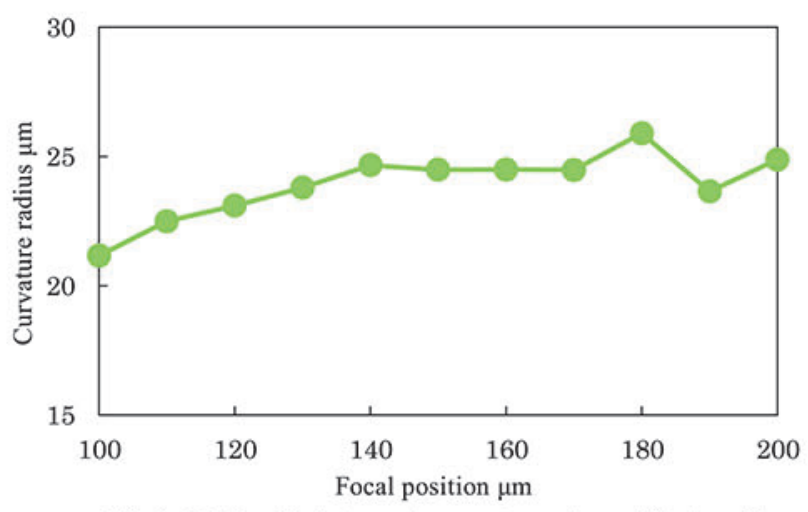

Fig.5 Relationship between the curvature radius and focal position

\section{3. レンズ型に適した凹面の追求}

\section{1 焦点位置による形状の変化}

レジストパターンの凹面形状を制御できるようにするため, 露 光量を $384 \mathrm{~mJ} / \mathrm{cm} 2$ としたまま, 焦点位置をより細かく変化させ, 曲率半径の変化傾向をレーザー顕微鏡 (Keyence, VK-X130) を 用いて钼察した. レンズの曲率半径は断面形状の変曲点と変曲点 の間とした.測定した筒所を図 4 に示す. 焦点位置を $0 \mu \mathrm{m}$ から $+200 \mu \mathrm{m}$ まで $10 \mu \mathrm{m}$ 毎に変化させてパターンを形成したときの凹 面パターン曲率半径の変化を図 5 に示す. グラフより, 焦点位置 をレジスト表面から上方にずらすほど曲率半径が増加することが 分かった. しかし, 図 6 に示寸ように焦点位置 $+100 \mu \mathrm{m} \sim+130 \mu \mathrm{m}$ の間ではパターン底部が平坦な形状となった. 目標形状を球面レ ンズとし, 球面レンズからの誤差が $0.1 \mu \mathrm{m}$ 以下の形状を良好な形 状として判断したが, レンズの形状は不適切であった. また, $170 \mu \mathrm{m}$ から $200 \mu \mathrm{m}$ の間では, 凹面レンズ型として利用できる部 分が小さくなってしまうことが分かった.

そして, 焦点位置を変更するときにレンズ形状が良好に 得られる範囲は $+140 \mu \mathrm{m}$ から+160 $\mu \mathrm{m}$ の間であることがわ かった. 


\begin{tabular}{|c|c|}
\hline Position Dose \\
\hline$+100 \mu \mathrm{m}$ \\
\hline$+110 \mu \mathrm{m}$ \\
\hline$+120 \mu \mathrm{m}$ \\
\hline$+130 \mu \mathrm{m}$ \\
\hline$+140 \mu \mathrm{m}$
\end{tabular}

Fig.6 Lens not in proper shape

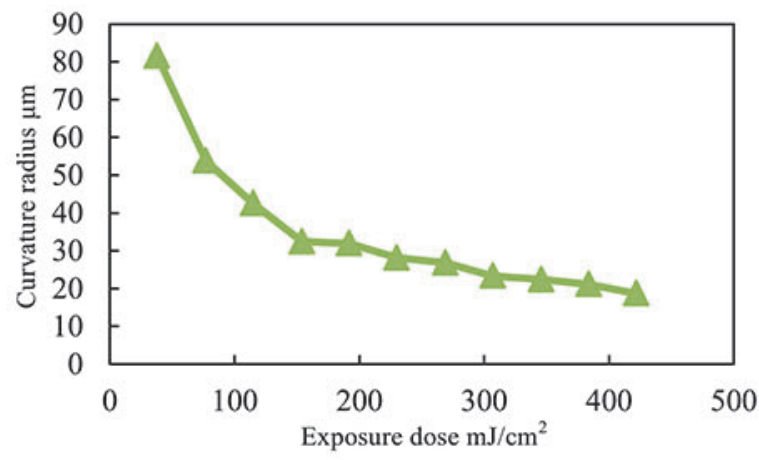

Fig.7 Relationship between exposure time and curvature radius of resist patterns

\section{2 露光量による形状の変化}

次に露光量による曲率半径の変化を調べた. ウエハに照射され た光の光強度 $J$ を測定したところ $0.64 \mathrm{~mW} / \mathrm{cm}^{2}$ であった. 露光時 間を $S$, 露光量(ドーズ)を $W\left(\mathrm{~mJ} / \mathrm{cm}^{2}\right)$ で示すとき, 露光量は

$$
W=\frac{J}{s}
$$

で表すことができる. そこで, 露光時間で露光量を調整して露光 実験を行った. 結果を図 7 に示す.

3.1 節と同様にレンズ底部が平坦になる傾向が見られた. また, 露光量が $384 \mathrm{~mJ} / \mathrm{cm}^{2}$ を超えると目標の形状である, 球面凹レンズ 型として利用できる球面の範井が小さくなる傾向が見られた. そ して, 露光量 $230 \mathrm{~mJ} / \mathrm{cm}^{2} \sim 384 \mathrm{~mJ} / \mathrm{cm}^{2}$ の間で球面レンズに近い形 状が形成されることがわかった.

\section{3 レチクルパターン寸法の影響}

次にレチクルによるレンズパターンの曲率半径の変化を調ベ るため, 六角最密配置のレチクルに代えて正方形穴レチクルで露 光を行った. 六角形穴径 $500 \mu \mathrm{m}$, 間隔 $400 \mu \mathrm{m}$ のレチクルと正方 形穴直径 $800 \mu \mathrm{m}$, 間隔 $200 \mu \mathrm{m}$ のレチクルで露光を行い, レジス トパターンの形状を比較した. デフォーカス位置 $+150 \mu \mathrm{m}$, 露光 量 $384 \mathrm{~mJ} / \mathrm{cm}^{2}$ の条件で得られたレジストパターンの断面を図 8 に 示寸.

レチクルの穴径を広げた場合も, パターン底部に平坦な 形状が形成されることがわかった.このレチクルで焦点位 置や露光時間を変更しても, 平坦部分が曲面形状になるこ とはなかった.これにより, レチクルの穴径を広げるとレ ンズに適した曲面形状を形成することが困難になることが 分かった.

\section{4 レジスト膜厚の影響}

以上の実験ではレジスト膜厚を $10 \mu \mathrm{m}$ に固定して露光実験を行 っていた. その結果, 凹状レジストパターンの底部残膜が 0.5 2 $\mu \mathrm{m}$ とかなり薄くなった. そのため, パターン形状が膜肎に より高さ方向へのパターン形成が制約を受けている可能性が考え られた. そこで, レジストの膜厚を厚くして露光を行い, 深さ方 向の制約を排除しようと考えた. 膜厚を $20 \mu \mathrm{m}$ として, 焦点位置 $+150 \mu \mathrm{m}$, 露光量 $384 \mathrm{~mJ} / \mathrm{cm}^{2}$ の条件で形成した正方形穴レジスト パターンの断面を図 9 に示す. 断面を見ると, レジストの厚さが 十分あっても, 露光条件次第で凹状パターンの底部が平坦になり 得ることを確認することができた.

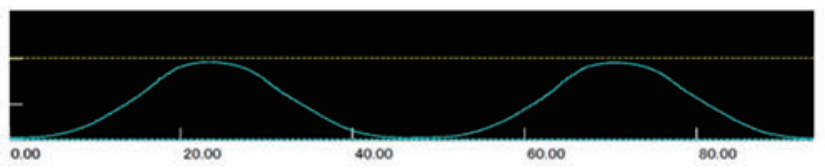

(a) Hexagonal holes with a diameter of $500 \mu \mathrm{m}$ and a space of $400 \mu \mathrm{m}$

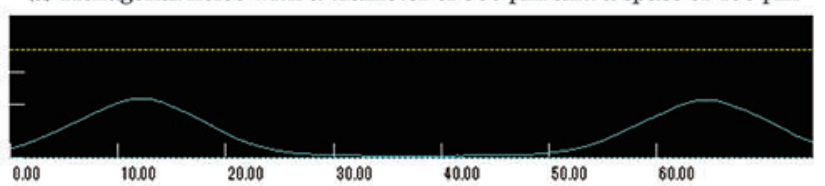

(b) Square holes with sides of $800 \mu \mathrm{m}$ and a space of $400 \mu \mathrm{m}$ Fig.8 Influence of reticle pattern size to lens shape

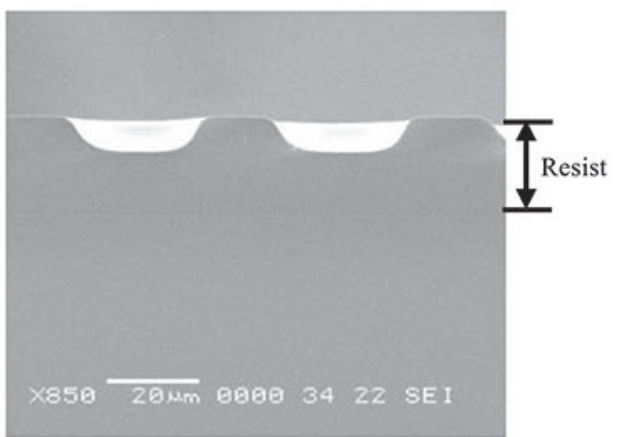

Fig.9 Concave patterns printed in $20 \mu \mathrm{m}$ thick resist 


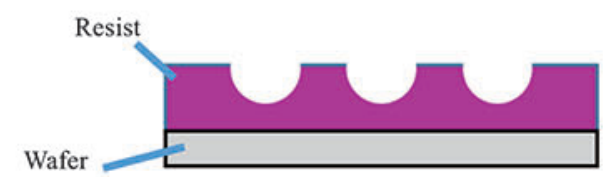

(a) Fabrication of resist mold

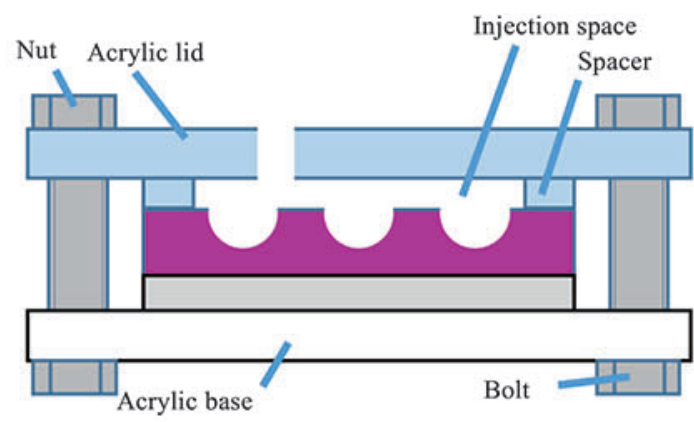

(b) Setup of lid and spacer

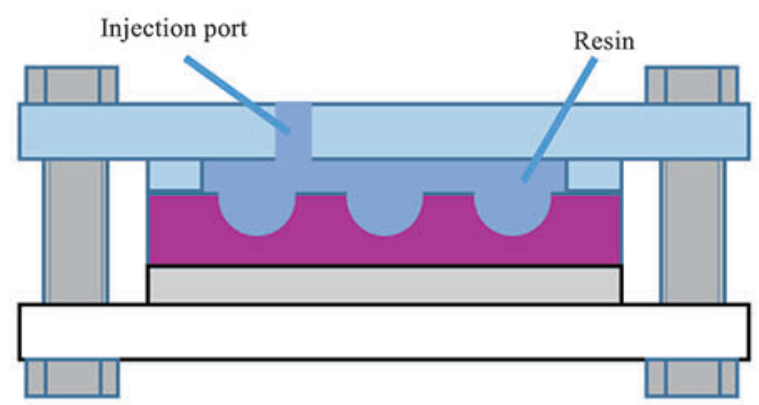

(c) Injection of liquid epoxy resin

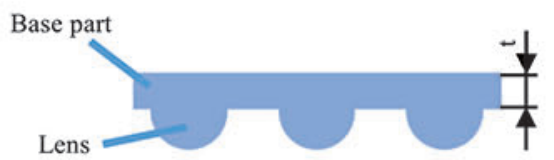

(d) Produced lens array

Fig.10 Newly developed fabrication method of micro-lens arrays

\section{4. 樹 脂 成 形}

\section{1 成形手順}

レジストによりマイクロレンズアレイパターン型を形成でき たので, 次に樹脂による成形を行った. 本研究では樹脂成形の代 表的な方法である射出成形を試みた. 射出成型は気泡が発生しづ らく, レンズ厚さを制御しや寸い. また, 研磨を行わないため傷 が付きにくい. 形成手順を図 10 に示す.

凹状レジストパターンを型に見立て, そこに樹脂を注入した. 三次元加工機でパターンに被せる上型を製作し, 樹脂の注入口を 設けた. また, $2 \mathrm{~mm}$ 角レンズアレイ部の基底部の厚さを $100 \mu \mathrm{m}$ にするために, 厚さ $100 \mu \mathrm{m}$ のシリコンシートを挟んだ. 一方, 図 示していないが, $2 \mathrm{~mm}$ 角のレンズパターン部を中心として, 半径 $5 \mathrm{~mm}$ の位置から外側の部分は, レンズ基底部が肉厚 $(2 \mathrm{~mm})$ にな るように, アクリル型の設計を行った. そうすることで, 硬化す る際の内部応力やガスの逃げ道を作り, 気泡の発生と剥離時の レンズの破損を抑止した. 樹脂を注入した後は, 放置して硬化さ せた. そして, 硬化した樹脂をアクリル型から㓲型し, レジスト を化学的に溶解除去してマイクロレンズアレイを製作した.

\section{2 樹脂選定}

透明樹脂としては, 変色せず, かつ低温で硬化する樹脂が好ま しい.レジスト型が所定温度を超えて熱せられると形状が変化し てしまうためである. そのためここでは, 硬化時に反応熱を比較 的発生しにくくて比較的安価な熱硬化性の樹脂（日新レジン, ク リスタルレジン NEO）を選定した.

レンズとしての適否を検討するために, まず紫外可視分光光度 計(日本分光, V-630) を用いて透過率を測定した. 結果を図 11 に 示す.

可視域の透過率は 85.7 88.9\%であった. また, 透過域は波長 $300 \mathrm{~nm}$ 以上であることが分かった.

次に, 波長 $650 \pm 5 \mathrm{~nm}$ の半導体赤色レーザーを立方体に成形し た樹脂ブロックに入射して屈折率を実測した. その結果, 屈折率 は $n=1.48$ であった. これらの光学特性から, 光学部品として利 用できるレンズアレイを作れると判断した.

\section{3 レンズ製作}

レンズの製作を行った. 樹脂硬化後に剥離を行う際に樹脂に付 着したレジストを強アルカリで溶解させることを試みた. しか し, レジストを溶解することはできなかった. この原因は, 周辺 部の樹脂を肉厚にした部分では発熱が䫓著なため, レジストが高 温になって硬化したためと考えた. そこで，レンズ形成部を取り 囲む広くて厚い周辺部分を切り取ってレンズ部のみを切出し, レ ジストを溶解したところレジストを除去することができた. レー ザー顕微鏡(キーエンス, VK-X100) により観察した樹脂レンズの 表面を図 12 に示す.

樹脂表面にマイクロレンズアレイがきれいに成形されている ことが分かる. 六角形のレチクルを用いたため, 真上から微察し たレンズ形状は若干六角形状を帯びてはいたが, かなり円形に近 くなり真円度誤差は $\pm 1 \mu \mathrm{m}$ 以内であった.

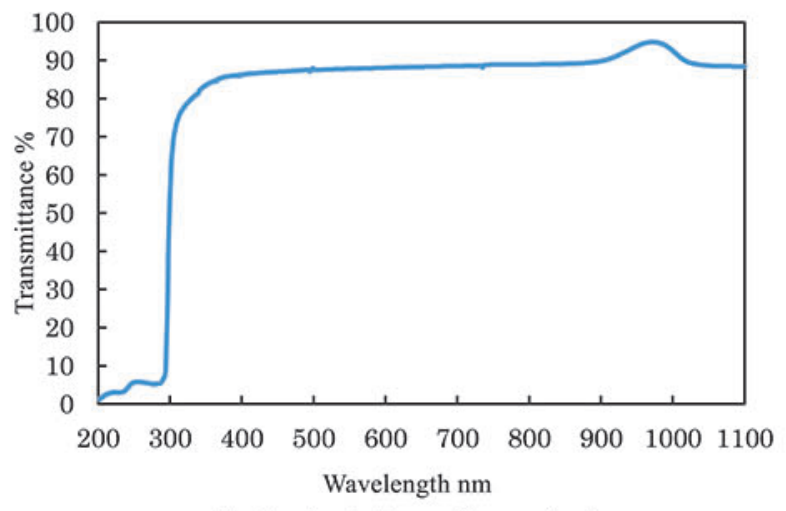

Fig.11 Spectral transmittance of resin

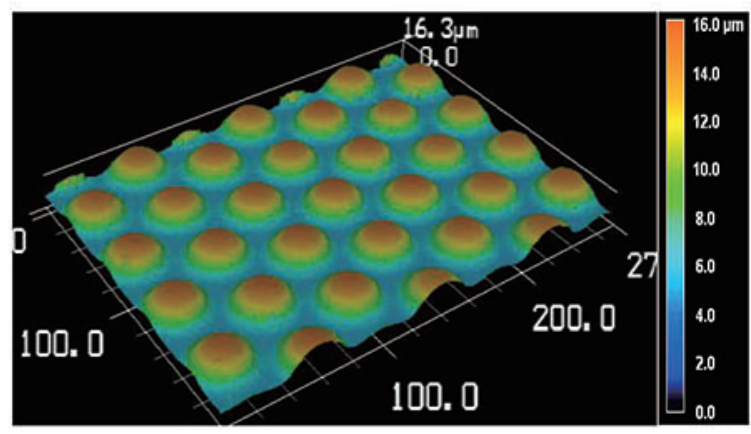

Fig.12 Surface of fabricated micro-lens array 
Table 1 Measured sizes of resist mold and resin lens.

\begin{tabular}{c|c|c}
\hline & Curvature radius & Depth or height \\
\hline Resist mold & $28.3 \mu \mathrm{m}$ & $5.1 \mu \mathrm{m}$ \\
\hline Resin lens & $26.7 \mu \mathrm{m}$ & $4.9 \mu \mathrm{m}$ \\
\hline Reduction ratio & 0.93 & 0.96 \\
\hline
\end{tabular}

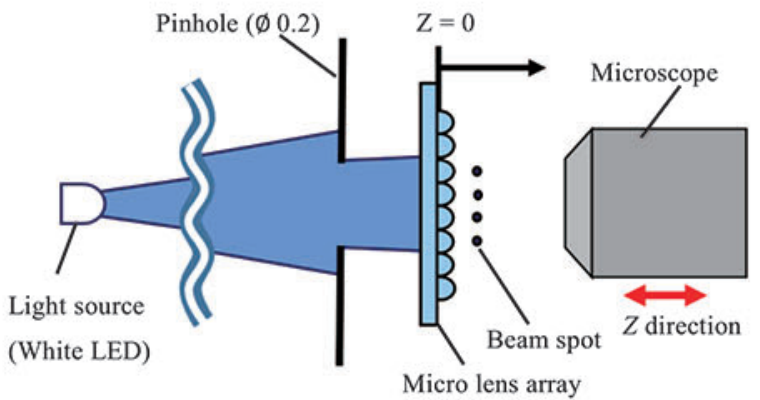

Fig.13 Setup for measuring the focal length

\section{5. 評 価 実 験}

\section{1 レジスト型と樹脂レンズの形状比較}

レーザー顕微鏡を使用してレジスト型の形状と成形した樹脂レ ンズ形状との寸法差を調べた. 結果を表 1 に示す. 目標とするレ ンズの曲率半径, 梁さは当面それぞれ $25 \mu \mathrm{m}, 5 \mu \mathrm{m}$ とした.

樹脂レンズの寸法は凹面レジスト型の寸法に比べて縮小して いた. これは硬化する際に樹脂から水分やガスが気化するため体 積が収縮したことが原因であると考えられる. そのため, レンズ 設計時にこの収縮率を考虑して製作することが必要である.

\section{2 焦点距離の測定}

製作したマイクロレンズアレイの焦点距雄を測定した. 焦点 距離の測定には, 光学式顕微鏡(アームシステム株式会社, IMZ-20CU) を用いた. 測定装置の構成を図 13 に示す.

白色 LED を光源として中央部の光を直径 $200 \mu \mathrm{m}$ のピンホー ルでほぼ平行光として取り出し, マイクロレンズアレイに入れ た. 最初に光学式䫓微鏡の焦点をマイクロレンズアレイのレン ズが形成されていない外周の平坦部に合わせ, 上下方向の位置 の原点 $(\mathrm{Z}=0)$ とした. 次に上下動ステージを上下して, マイクロ レンズを透過した光により形成されるピンホールの像が, 一番 小さくなる距離 $Z$ を探し, それをマイクロレンズアレイの焦点 距雄とした(図 14). 顕微鏡付属のカメラにより撮影した観察像 を図 15 に示す.

レンズ基底部に焦点を合わせたとき $(\mathrm{Z}=0)$ は全体がぼやけた 像が钼察され, Z を増やすと光スポットが現われ, 焦点位置 $22.5 \mu \mathrm{m}$ でもっともピンホールの像が小さくなった. これにより レンズの焦点距離は $22.5 \mu \mathrm{m}$ であることがわかった. また, 光ス ポットの径は $3 \mu \mathrm{m}$ であった. ピンホール径を $200 \mu \mathrm{m}$ としたの で, 像は 15/1000に縮小されたことが分かった. しかし, レンズ アレイの中心から周辺方向に離れるにつれてスポットの位置が レンズの中心直下から外れる方向にずれた. これは入射光が完 全な平行光束ではなく, 中心から外に広がる光束であったため と考えている.

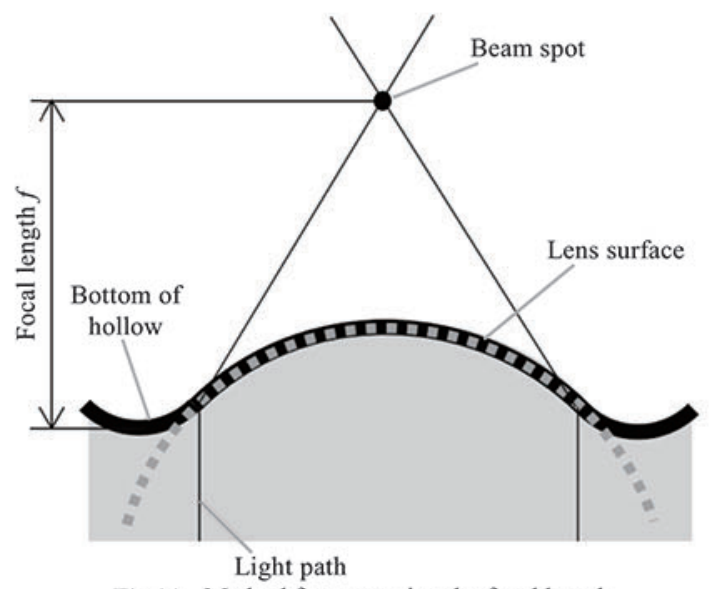

Fig.14 Method for measuring the focal length

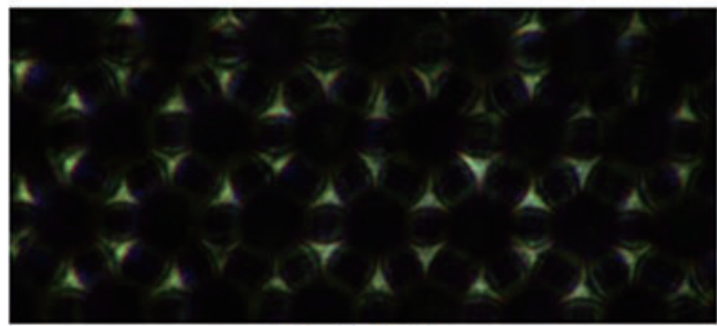

(a) $Z=0 \mu \mathrm{m}$

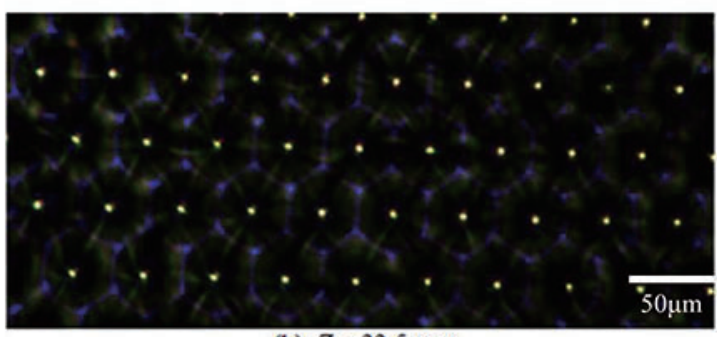

(b) $Z=22.5 \mu \mathrm{m}$

Fig.15 Observation results of light spots formed by the lens array

\section{6. 考 察}

焦点位置, 露光量, レチクル形状を変えるときのレジストパ ターン形状の変化を調べた. その結果, パターン底部が平らに なったりレンズ型として使える部分が小さくなったりして良好 なパターンを形成できる条件が限定されていた. ウエハをレン ズから維す方向に動かして焦点位置をずらす場合レジスト上部 の露光面積が小さくなり, レジスト下部は大きくなるため, レ ジスト上部の方が単位面積当たりの光照射量が大きくなる. ま た, レジストに光が吸収されるので, 上部ほど光強度が強く, こ の観点からもレジスト上部の方が下部より強く露光される. そ のため, 上部の方が下部よりかなり余分に露光され, その結果, レンズ型に丁度よい曲面形状が形成されると考えている. しか し，あまり焦点をずらしすぎると，回折により蘩り合った穴の 像の光と干涉し始め, レンズ型として使える部分が小さくなる. 露光量を増すとレジストの光透過率が上昇するためレジストに 吸収される光エネルギーが少ししかなくなり形状の変化が少な くなると考えられる. パターン底部が平坦になってしまう原因 の一つとして考えられるのは, レチクルのパターン穴の中央部 の光強度が均一になるためであると考えられる. デフォーカス 
によりレチクルの像の輪郭をぼやけさせて露光を行っているが, 像の輪郭から遠い中央部でぼかしの影響が無くなるため中央部 が平坦になってしまうと考えられる. これを解決するためには, 円環状に明暗を区切ったパターンを用いたレチクルや, グレー スケールのレチクルを用いることが考えられる. 中央部の光強 度を周辺より高くすることでパターン底部を曲面上に形成でき ると考えている. また, 波長 $405 \mathrm{~nm}$ の光により投影露光を行っ ているが, この波長の光がレジストを透過できる深さが, 凹状 パターン樑さの限界となる. 波長を長くすればより深い凹状パ ターンを形成できると考えている. また, この実験で示した各 パラメータの適切な值は, 他のパラメータの数值との干渉があ り, 露光量によって適切な焦点位置をレチクルの形状毎に設定 しなければならない. 露光量による形状変化は飽和するので, 露光量を多くとってから, 焦点位置を変えて断面形状を調べれ ば, 適切な位置を設定することができる.

断面形状の円弧からの誤差を改善するには丸穴を最密配置す ることが有効と考えている. 上記の実験ではレンズを密集させ, 露光領域を広く取りたかったため六角形穴レチクルを用いたが, レンズ形状が六角形に近いものになってしまうという問題があ った. そこで丸穴レチクルを用いてレンズを形成したところ, レンズ形状を円形に近づけることできた. 結果を図 16 に示す. また, 六角形穴レチクルと丸穴レチクルを用いて製作したレン ズ断面形状を対角方向と対辺方向に測定した結果を図 17 に示寸. レンズとして使用できる領域のみで比較するための綐線で挟ま れた部分において, 対角を結んだ断面と対辺の中点を結んだ断 面を表わす曲線に囲まれる微小面積を「パターン誤差」と定義 すれば, パターン誤差は六角穴レチクルが $0.389 \mu \mathrm{m}^{2}$, 丸穴レチ クルが $0.150 \mu \mathrm{m}^{2}$ であり, 丸穴レチクルの方がレンズの方位によ る断面形状の相異が少ないことがわかった. これは六角形レチ クルの角部の回折が丸穴になったことで全方位均等になったた めと考えている. 今後は丸型レチクルでの実験を行っていきた い.

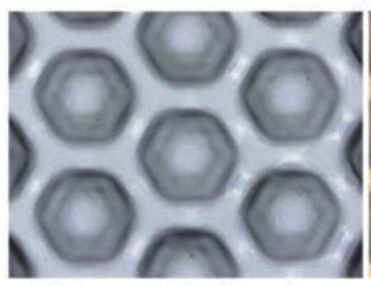

(a) Lenses obtained by using a with hexagonal patterns

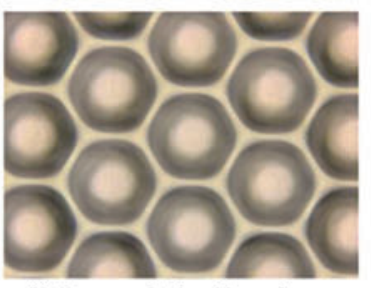

(b) Lenses obtained by using a with circular patterns
Fig.16 Comparison of shape deformations between lenses fabricated by using reticles with hexagonal and circular patterns

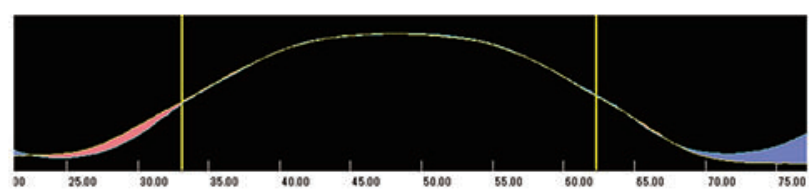

(a) Hexagonal pattern

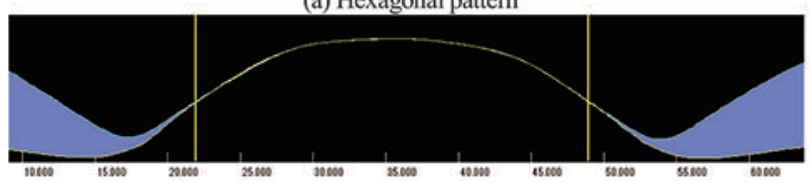

(b) Circular pattern

Fig.17 Comparison of profile curve errors between lenses fabricated by using reticles with hexagonal and circular patterns

\section{7. 結言}

本研究では以下のような結果を得た.

（1）投影露光リソグラフィを用い, 焦点位置を垂直側壁が 形成できる条件から意図的に大きくずらすことによっ て, マイクロ凸レンズアレイの型とする凹面パターン をレジスト表面に形成した.

（2）焦点位置, 露光量, レチクル寸法を調整することで利用 可能なレンズ形状が得られる条件と範囲を明らかにし た.

（3）成形したマイクロレンズの特性を評価した. 直径約 $3 \mu \mathrm{m}$ の光スポットアレイを得ることができ, 焦点距離 を測定した結果, $22.5 \mu \mathrm{m}$ であった.

\section{参 考 文 献}

1) A. Fernández, J. Medina, C. Benkel, M. Guttmann, B. Bilenberg, L. H. Thamdrup, T. Nielsen, C. M. S. Torres and N. Kehagias: Residual Rayer-free Reverse Nanoimprint Lithography on silicon and Metal-coated Substrates, Microelectronic Engineering, 141, (2015) 56.

2) A. Yokoo and H. Namatsu: Nanoelectrode lithography using a flat mold with a pattern defined by different conductivities, Microelectronic Engineering, 87, (2010) 931.

3) C. Steinberg, M. Papenheim, S. Wang and H. C. Scheer: Complex 3D structures via hybrid processing of SU-8, Microelectronic Engineering, 155, (2016) 14.

4) X. Fang, C. Lin, Y. Sun, H. Chin, H. Zan, H. Meng, S. Horng and L. A. Wang: A solvent-free lift-off method for realizing vertical organic transistors with low leakage current and high ON/OFF ratio, Organic Electronics, 31, (2016) 227.

5) T. S. Kulmala, E. Buitrago, M. Vockenhuber and Y. Ekinci: Pattern collapse mitigation in inorganic resists via a polymer freeze technique, Microelectronic Engineering, 155, (2016) 39.

6) J. Lauria, R. Albright, O. Vladimirsky, M. Hoeks, R. Vanneer, B. Drieenhuizen, L. Chen, L. Haspeslagh and A. Witvrouw: SLM device for $193 \mathrm{~nm}$ lithographic applications, Microelectronic Engineering, 86, (2009) 569 .

7) Z. Yanga, Y. Zhanga and T. Itoha: Fabrication of a MEMS Temperature Sensor on the Capillary Surface for Hyperthermia Intervention Monitoring, Procedia Engineering, 47, (2012) 96.

8) N. Ferrell, J. Woodard and D. J. Hansford: Measurement of cell forces using a microfabricated polymer cantilever sensor, Sensors and Actuators, A 170, (2011) 84.

9) M. Peraltaa, J. L. Costa-Krämerb, E. Medinaa and A. Donosoa: Analysis and fabrication steps for a 3D-pyramidal high density coilelectromagnetic micro-generator for energy harvesting applications, Sensors and Actuators, 205, (2014) 103.

10) H. Rodriguea, B. Bhandaria,b, W. Wanga and S. Ahna: 3D soft lithography: A fabrication process for thermocurable polymers, Journal of Materials Processing Technology, 217, (2015) 302.

11) B. Farkas, I. Romano, L. Ceseracciu, A. Diaspro, F. Brandi and S. Beke: Four-order stiffness variation of laser-fabricated photopolymer biodegradable scaffolds by laser parameter modulation, Materials Science and Engineering, C 55, (2015) 14.

12) X. Maa, Y. Katoa, F. Kempenb, Y. Hiraia,*, T. Tsuchiyaa, F. Keulenb and O. Tabataa: Multiple Patterning with Process Optimization Method for Maskless DMD-Based Grayscale Lithography, Procedia Engineering, 120, (2015) 1091.

13) L. A. Mosher, C. M. Waits, B. Morgan, and R. Ghodssi: A NEW PARADIGM FOR HIGH RESOLUTION 3D LITHOGRAPHY, MEMS Sensors and Actuators Laboratory, (2008) 13.

14) Dengfeng Kuang, Xiaoliang Zhang, Min Gui, and Zhiliang Fang: Hexagonal microlens array fabricated by direct laser writing and inductively coupled plasma etching on organic light emitting devices to enhance the outcoupling efficiency, APPLIED OPTICS, 48, (2009) 5.

15) Hongkai Wu, Teri W. Odom, and George M. Whitesides: Reduction Photolithography Using Microlens Arrays: Applications in Gray Scale Photolithography, Analytical Chemistry, 7, 14, (2002) 3267.

16) Hsin-Chung Cheng, Chiung-Fang Huang, Yi Lin, Yung-Kang Shen: Brightness field distributions of microlens arrays using micro molding, OPTICS EXPRESS, 18, 26, (2010) 26887.

17) S. C. Shen and J. C. Huang: Rapid fabrication of a micro-ball lens array by 
extrusion for optical fiber applications, OPTICS EXPRESS, 17, 15, (2009) 13122.

18) Hoang-Yan Lin, Yu-Hsuan Ho, Juin-Haw Lee, Kuan-Yu Chen, Jheng-Hao Fan, Sheng-Chih Hsu, Mao-Kuo Wei, Hung-Yi Lin, Jen-Hui Tsai and Tung-Chuan Wu: Patterned microlens array for efficiency improvement of small-pixelated organic light-emitting devices, OPTICS EXPRESS, 16, 15, (2008) 11044.

19) T. Horiuchi and R. Sasaki: New Fabrication Method of Plastic Micro-Lens Arrays for Researching on Compound Eyes of Insects, Proceedings of 9th Biomedical Engineering Systems and Technologies, 1, (2016) 40.

20) T. Horiuchi and R. Sasaki: Fabrication of Concave Resist Patterns for the Use of Reversal Molds of High-Density Micro-Lens Arrays, Journal of Photopolymer Science and Technology, 29, (2016) 595.

21) N. Kobayashi, R. Sasaki and T. Horiuchi: Fabrication of Micro-Lens Arrays Utilizing Lithographically Replicated Concave Resist Patterns, Proceeding of $16^{\text {th }}$ International Conference on Precision Engineering, 9984, (2016) 56

22) Feng Chen, Hewei Liu, Qing Yang, Xianhua Wang, Cong Hou, Hao Bian, Weiwei Liang, Jinhai Si, and Xun Hou: Maskless fabrication of concave microlens arrays on silica glasses by a femtosecond-laser-enhanced local wet etching method, OPTICS EXPRESS, 18, 19, (2010) 20334.

23) Zefang Deng, Feng Chen, Qing Yang, Hewei Liu, Hao Bian, Guangqing Du, Yang $\mathrm{Hu}$, Jinhai Si, Xiangwei Meng and Xun Hou: A facile method to fabricate close-packed concave microlens array on cylindrical glass, JOURNAL OF MICROMECHANICS AND MICROENGINEERING, 22, (2012) 11.

24) Takanobu Oba, Yoshimi Takeuchik, Tomohiko Kawai, Hideo Takino: Ultraprecision Multi-Axis Control Machining of Spherical Micro-Lens Array Mold, JSPE Autumn Meeting, (2008) 129.

25) Jiwang Yan, Akihiro Horikoshi, and Tsunemoto Kuriyagawa: Manufacturing of Large-area Microstructure Arrays by Combining Micro Indentation and Ultraprecision Cutting, JSPE Autumn Meeting, (2009) 63.

26) Young Jin Noh, Makoto Tano, Yoshikazu Arai, Wei Gao, Development of a Fast Tool Servo Unit Combined a Force Sensor -Experiment for detection of initial position of machining-, JSPE Autumn Meeting, (2007) 427. 